\title{
Assimilate partitioning in leaves of the raffinose-storing herb Lamium album L.: the effects of altering source-sink balance
}

\begin{abstract}
A. KOCHHAR ${ }^{1,2,3}$, T. AP REES ${ }^{1,4}$ and C.J. POLLOCK ${ }^{2,5}$
(received: January 29, 2003; accepted: September 18, 2003)

ABSTRACT - (Assimilate partitioning in leaves of the raffinose-storing herb Lamium album L.: the effects of altering sourcesink balance). In Lamium album, sucrose and raffinose-family oligosaccharides are the major products of photosynthesis that are stored in leaves. Using gas analysis and ${ }^{14} \mathrm{CO}_{2}$ feeding, we compared photosynthesis and the partitioning of recently-fixed carbon in plants where sink activity was lowered by excision of flowers and chilling of roots with those where sink activity was not modified. Reduction in sink activity led to a reduction in the maximum rate of photosynthesis, to retention of fixed carbon in source leaves and to the progressive accumulation of raffinose-family oligosaccharides. This ultimately affected the extractable activities of invertase and sucrose phosphate synthase. At the end of the light period, invertase activity was significantly higher in treated plants. By contrast sucrose phosphate synthase activity was significantly lower in treated plants. We propose that reducing sink activity in L. album is associated with a shift in metabolism away from starch and sucrose synthesis and towards sucrose catabolism, galactinol utilisation and the synthesis of raffinose-family oligosaccharides.
\end{abstract}

Key words - Lamium album, oligosaccharides, source-sink interactions, starch, sucrose

RESUMO - (Partição de assimilados em folhas de Lamium album L., uma planta herbácea que acumula rafinose: os efeitos da alteração do balanço fonte-dreno). Em Lamium album, sacarose e oligossacarídeos da família rafinósica (OFR) são os principais produtos da fotossíntese que são armazenados nas folhas. Utilizando análise de trocas gasosas e fornecimento de ${ }^{14} \mathrm{CO}_{2}$ foram comparadas a fotossíntese e a partição de carbono recentemente fixado, em plantas nas quais a atividade dreno foi reduzida através da excisão das flores e resfriamento das raízes, com plantas nas quais a intensidade de dreno não foi modificada. A redução da atividade de dreno levou a uma diminuição na taxa máxima de fotossíntese, à retenção de carbono fixado nas folhas fonte e a um acúmulo progressivo dos OFR. Isso afetou as atividades extraíveis de invertase e sacarose fosfato sintase. Ao final do período de luz, a atividade de invertase foi significativamente maior nas plantas tratadas. Em contraste, a atividade de sacarose fosfato sintase foi significativamente menor nas plantas tratadas. Nós propomos que a redução da atividade de dreno em L. album esteja associada a uma alteração metabólica não relacionada ao metabolismo de síntese de amido e sacarose, mas sim ao catabolismo da sacarose, utilização de galactinol e síntese de OFR.

Palavras-chave - amido, interações fonte-dreno, Lamium album, oligosacarídeos, sacarose

\section{Introduction}

Long-distance interactions between sources and sinks in plants affect both photosynthesis and carbon partitioning (Farrar et al. 2000). Both increased photosynthesis and reduction of sink activity may result in the accumulation of carbohydrates in leaves. Sucrose and starch are the major immediate products of photosynthesis although some plant species accumulate

1. University of Cambridge Department of Plant Sciences, Downing Street, Cambridge CB2 3EA, UK.

2. Institute of Grassland and Environmental Research, Plas Gogerddan, Aberystwyth SY23 3EB, Wales, UK.

3. Current address: 10301 Devonshire Road \#119, Bloomington, MN 55431, USA.

4. Professor ap Rees initiated this study with Dr Kochhar in Cambridge prior to his untimely death in October 1996. It was completed in the corresponding author's laboratory in Aberystwyth.

5. Corresponding author: chris.pollock@bbsrc.ac.uk a range of other carbohydrates (Pollock et al. 1999). Accumulation of sugars in leaves can be associated with a decline in the activities of enzymes involved in carbohydrate synthesis and ultimately result in feed back inhibition of both sucrose synthesis and photosynthesis (Stitt 1996, Farrar et al. 2000). The extent of feed back inhibition varies from plant to plant. In plants such as soybean, cotton and cucumber, which store starch in their leaves, feed back inhibition is observed, while there is less evidence of inhibition in plants like spinach which store sucrose in their leaves (Goldschmidt \& Huber 1992). Studies on fructanaccumulating monocots (which store very little starch in the leaves) indicate that photosynthetic downregulation is minimal, perhaps due to the vacuolar sequestration of carbohydrate (Farrar et al. 2000). In a previous paper, we described the partitioning of carbon in leaves of Lamium album L. (Kochhar et al. 2003). L. album was used because raffinose family 
oligosaccharides (RFOs) are major products of photosynthesis along with sucrose and starch, and this species therefore provides a contrast between high starch leaves and those of low-starch fructanaccumulators. Measurement of carbohydrate content showed that sucrose and starch were more abundant than RFOs in leaves of L. album grown under moderate irradiance with high sink activity (Kochhar et al. 2003). We suggested that only sucrose was synthesized at the beginning of the light period, with RFO and/or starch synthesis becoming significant later in the photoperiod.

In the study reported here, the activities of the major sinks (roots and flowers) were reduced in order to decrease sink demand. The effects of the resulting accumulation of photosynthetic products on carbon partitioning, photosynthesis and enzyme activities were determined. It is generally accepted that the activities of enzymes of both sucrose synthesis (e.g. sucrose phosphate synthase (SPS; Kerr \& Huber 1987, Gerhardt et al. 1987) and sucrose degradation (e.g. invertase; Huber 1989) are regulated by the concentration of sucrose inside the cytosol. Sucrose accumulation may, therefore, be associated with the inhibition of SPS and the stimulation of the activities of invertase isoforms (Walker et al. 1997, Kingston-Smith et al. 1998).

\section{Material and methods}

Plant cultivation and physiological treatments - Plants of Lamium album L. (white dead nettle) were grown hydroponically from cuttings in controlled environment conditions as described previously (Kochhar et al. 2003). Growth temperature was $20^{\circ} \mathrm{C}$, photoperiod $12 \mathrm{~h}$, irradiance $500-550 \mu \mathrm{Em}^{-2} \mathrm{~s}^{-1}$. Carbon partitioning, photosynthesis and enzyme activities were measured under two contrasting conditions. In sink-limited (treated) plants, roots were chilled by circulating ethylene glycol at $4{ }^{\circ} \mathrm{C}$ through the nutrient solution and developing flowers were pinched off. Experiments were begun thirty-six $\mathrm{h}$ after sink manipulation was imposed. This delay overcame the direct effects of treatment on stomatal closure. Control plants were grown without any sink manipulation.

Gas exchange measurements - Measurements were made on fully-mature leaves at a range of times during the photoperiod on a number of occasions following sink manipulation. For comparative purposes, only the results for the third photoperiod after sink manipulation are presented. Net $\mathrm{CO}_{2}$ exchange, transpiration, stomatal conductance and intercellular $\mathrm{CO}_{2}$ concentrations were measured using a PP Systems CIRAS-1 gas analyser with a clip-on leaf cuvette (Lewis et al. 1999). $A_{\max }$ values were measured using a Hansatech leaf disk oxygen electrode under saturating irradiance and $\mathrm{CO}_{2}$ concentrations (Housley \& Pollock 1985). Feeding ${ }^{14} \mathrm{CO}_{2}$ to intact plants of L. album - Replicate groups of ten hydroponically-grown plants were taken for ${ }^{14} \mathrm{CO}_{2}$ feeding. Because of the opposed pattern of leaf development in L. album, two feeding chambers were constructed, each of which held ten source leaves, each from a different plant. These chambers were arranged in parallel, with the plants in between them, inside a larger perspex chamber $(123 \times 29 \times$ $41 \mathrm{~cm}$ ). Connectors were sealed into the large chamber to allow coolant to be circulated through the root nutrient solution and there were fans on the upper surface to promote air movement. The two feeding chambers $(112 \times 7.5 \times 2.5 \mathrm{~cm})$ had removable lids and the inner walls had ten equally distant notches $(4 \times 3 \mathrm{~mm})$ milled into the upper surface. The roots were kept in aerated nutrient solution that, for treated plants, could be cooled via a heat exchanger linked to an external constant temperature water bath. The plants were moved into the outer chamber two nights before the experiment, and were kept at $500-550 \mu \mathrm{Em}^{-2} \mathrm{~s}^{-1}$. On the day of the experiment, prior to illumination, the petioles of fully-mature attached leaves were sealed into the slots with Blu-Tak and the lids replaced.

Both control and treated plants were illuminated for twenty minutes with $\mathrm{CO}_{2}$-free air being passed through the feeding chambers for the last 10 minutes. ${ }^{14} \mathrm{CO}_{2}$ was then administered to 20 mature leaves from 10 plants ( 10 leaves in each chamber). Sodium $\left[{ }^{14} \mathrm{C}\right]$ bicarbonate $(1.2 \mathrm{~mL} ; 2.4 \mathrm{mci})$ was injected into each feeding chamber onto excess lactic acid. The feeding period was $30 \mathrm{~min}$, after which the chamber was flushed with ambient air for $10 \mathrm{~min}$. $\mathrm{KOH}(10 \% \mathrm{v} / \mathrm{v})$ was used to trap the unfixed ${ }^{14} \mathrm{CO}_{2}$. During the subsequent chase period, ambient air was passed through the chambers. Duplicate plants were harvested after $1 \mathrm{~h}$ (immediately after feeding), $6 \mathrm{~h}$ (after $6 \mathrm{~h}$ illumination), $12 \mathrm{~h}$ (after $12 \mathrm{~h}$ illumination), $18 \mathrm{~h}$ (12 h light, $6 \mathrm{~h}$ of the subsequent dark period) and $24 \mathrm{~h}(12 \mathrm{~h}$ light, $12 \mathrm{~h}$ of the subsequent dark period). Extraction, fractionation and measurement of radioactivity was carried out as described previously (Kochhar et al. 2003). Soluble material was fractionated by ion exchange chromatography into an acidic fraction (organic acids plus acid-stable phosphorylated intermediates); a basic fraction (mainly amino acids) and a neutral fraction (carbohydrates). The neutral fraction was separated further by TLC, sugars were identified by co-chromatography with markers and radioactivity quantified by autoradiography/densitometry (Kochhar et al. 2003). Insoluble material was counted directly following solubilisation and aliquots were also digested with amyloglucosidase/ á-amylase and the glucose released from starch separated by TLC (Kochhar et al. 2003). During the chase period, respired ${ }^{14} \mathrm{CO}_{2}$ was trapped by passage through $\mathrm{KOH}(10 \% \mathrm{v} / \mathrm{v})$ and aliquots counted by liquid scintillation spectrometry.

Enzyme extraction and assay - SPS and invertase activities were measured in extracts from the middle leaves of $L$. album harvested $0,4,8,12,18$ and $24 \mathrm{~h}$ after the beginning of the photoperiod commencing thirty-six $\mathrm{h}$ after sink manipulation 
for treated plants. The light period was $12 \mathrm{~h}$. Concentrations of substrates as well as incubation time, temperature and $\mathrm{pH}$, were optimized to obtain $\mathrm{V}_{\text {max }}$ estimates. For the extraction of enzymes, leaf samples were harvested and ground in liquid $\mathrm{N}_{2}$. Weighed samples (200-300 mg) of the powdered leaves were placed in a $2 \mathrm{~mL}$ screw-capped microtube and extracted according to Huber et al. (1989). The extracts were desalted prior to assay.

Assay of SPS - The activity of SPS was determined under $\mathrm{V}_{\max }$ conditions by measuring fructose-6-phosphatedependent formation of sucrose and sucrose-P from uridine diphosphoglucose. Substrate concentrations were as described in Huber et al. (1989) except that fructose-6phosphate was at $5 \mathrm{mM}$.

Assay of invertase - Invertase was assayed by measuring the release of glucose and fructose from sucrose under the conditions described by Lyne \& ap Rees (1971) except that the assay $\mathrm{pH}$ was 4.5 . Released glucose and fructose were determined using a microtitre plate reader. In each well $10-100 \mu \mathrm{L}$ of the assay mix was added together with $200 \mu \mathrm{L}$ of buffer containing $50 \mathrm{mM} \mathrm{HEPES}$ ( $\mathrm{pH} 7.5$ ), $5 \mathrm{mM} \mathrm{MgCl}_{2}, 10 \mathrm{mM}$ $\mathrm{NAD}^{+}, 10 \mathrm{mM}$ ATP. The reaction was started by the addition of $5 \mu \mathrm{L}$ of enzyme cocktail containing $1 \mathrm{U} \mathrm{mL}^{-1}$ of phosphoglucose isomerase, $1 \mathrm{U} \mathrm{mL}^{-1}$ of hexokinase and $1 \mathrm{U} \mathrm{mL}^{-1}$ of glucose-6-phosphate dehydrogenase. The overall increase in absorbance at $340 \mathrm{~nm}$ was measured for each well.

\section{Results}

Photosynthetic parameters - These are summarized in figure 1 for mature leaves in control and sinkmanipulated (treated) plants measured at various times during the photoperiod three days after sink manipulation. Similar results were obtained from other measurements made over a seven-day period following sink manipulation. In all cases, photosynthesis was reduced in treated plants, as was stomatal conductance. This was accompanied by a reduction in transpirational water loss but no significant increase in intracellular $\mathrm{CO}_{2}$ content. $A_{\max }$ values over the first three days following sink manipulation showed a significant and persistent reduction in treated plants (figure 2). These results suggest that photosynthesis declined due both to stomatal regulation (Setter \& Brun 1980) and to downregulation of photosynthesis (Suwignyo et al. 1995). Total radioactivity - The distribution of radioactivity in middle leaves of control and treated plants is shown in figure 3. Immediately after the feeding period, the total amount of radioactivity was lower in treated than in control plants. This is probably due to the lower rate of photosynthesis and decreased stomatal conductance observed in treated plants (figure 1). During the dark period, total radioactivity increased in the middle leaves of treated plants. It is possible that, in the absence of other sinks, the younger leaves of treated plants acted as temporary sinks and that secondary transfer of radioactivity was responsible for this increase. Autoradiographs of ${ }^{14} \mathrm{CO}_{2}$-fed plants (results not shown) indicated much greater retention of radioactivity in the leaves of treated plants throughout the $24 \mathrm{~h}$ chase period. Immediately after the feeding period, more radioactivity

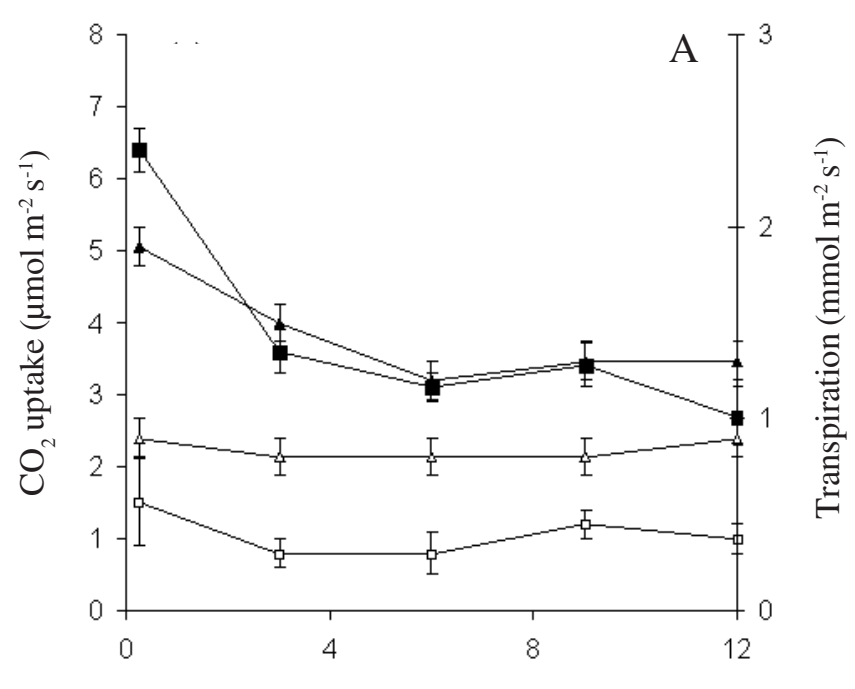

Time into photoperiod (h)

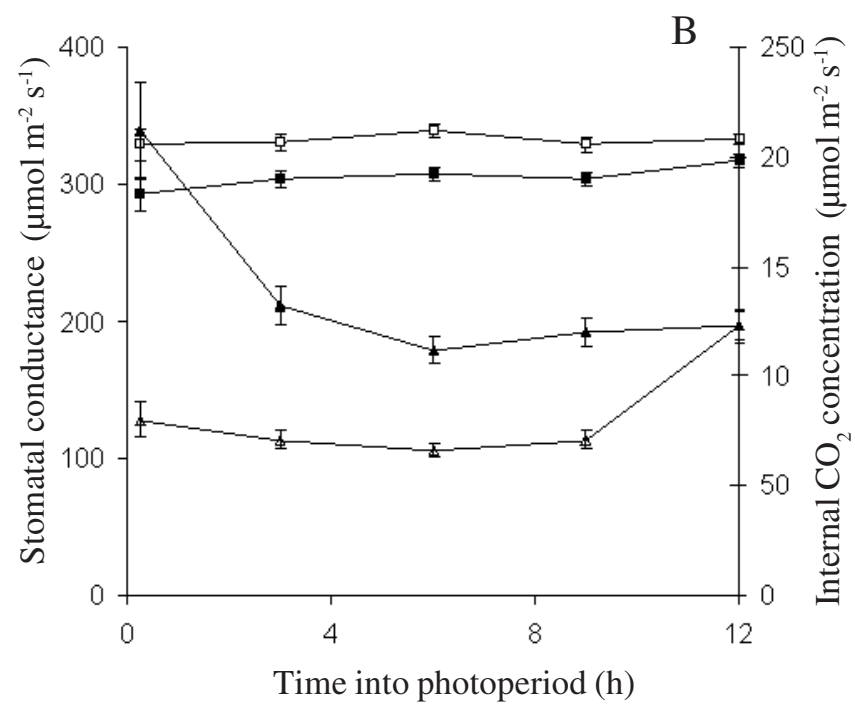

Figure 1. Photosynthetic paprameters measured in mature leaves of Lamium album at various times during the photoperiod. Measurements were made three days after the imposition of root cooling and flower removal in treated plants. Values are means \pm sem of at least eight determinations. Closed symbols control plants; open symbols treated plants. $\mathrm{A}: \boldsymbol{\square}=\mathrm{CO}_{2}$ uptake; $\boldsymbol{\Delta}=$ transpiration. $\mathrm{B}: \mathbf{\square}=$ internal $\mathrm{CO}_{2}$ concentration; $\boldsymbol{\Delta}=$ stomatal conductance. 


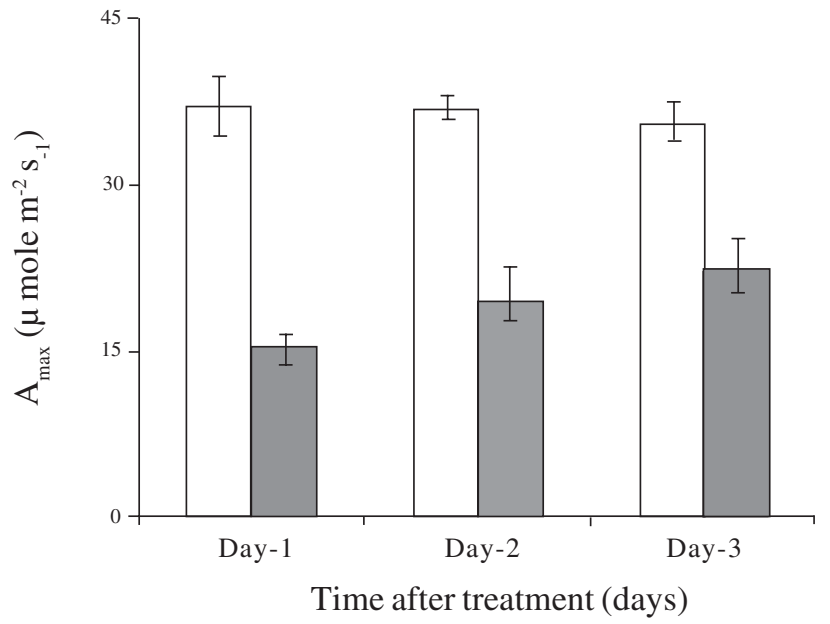

Figure 2. $A_{\max }$ values for mature leaves of control $(\square)$ and treated $(\square)$ plants harvested at various times after cooling of roots and removal of flowers. Values are means \pm sem of five individual samples, measured mid-way through the light period.

was released as ${ }^{14} \mathrm{CO}_{2}$ from treated plants than from control plants. The amount of ${ }^{14} \mathrm{CO}_{2}$ released from both types of plant fell steadily during the chase period (figure 3).

Distribution of radioactivity within mature leaves Treated plants had more radioactivity in the soluble fraction than did control plants (figure 4A, B). In both cases, radioactivity decreased in the soluble fraction with time and increased in the insoluble fraction until the end of the chase period. Generally, treated plants accumulated less radioactivity in the insoluble fraction and in starch than did control plants.

Distribution of radioactivity within soluble components The middle leaves from treated plants had a greater proportion of the retained radioactivity in neutral components throughout the chase period (figure 4C, D). In the basic fraction, radioactivity in control leaves was almost double than in treated leaves between 6 and $24 \mathrm{~h}$. We suggest that the high proportion of radioactivity in the neutral components of extracts from mature leaves of treated plants was due to reduction in export associated with sink manipulation. The pattern of changes in radioactivity over time differed between control and treated leaves. The highest percentage of radioactivity in the neutral fraction from control plants was observed immediately after the feeding period. It was then relatively stable till $18 \mathrm{~h}$, whilst the opposite was observed in treated plants. The subsequent decrease in neutral sugars in control plants could be due to transport into sink tissues or repartitioning into the chloroplast as starch.
Further analysis of the neutral fractions from middle leaves of both control and treated plants indicated that substantial amounts of radioactivity were present in stachyose, raffinose and galactinol as well as in sucrose (figure 4E, F). In control plants, the radioactivity in sucrose fluctuated throughout the chase period, whereas it was more stable in treated plants. At $12 \mathrm{~h}$ (the end of the light period) treated leaves had more radioactivity in stachyose than in any other neutral sugar, whereas the opposite was true for control leaves. By contrast, the partitioning of radioactivity into galactinol was greater in the control leaves.
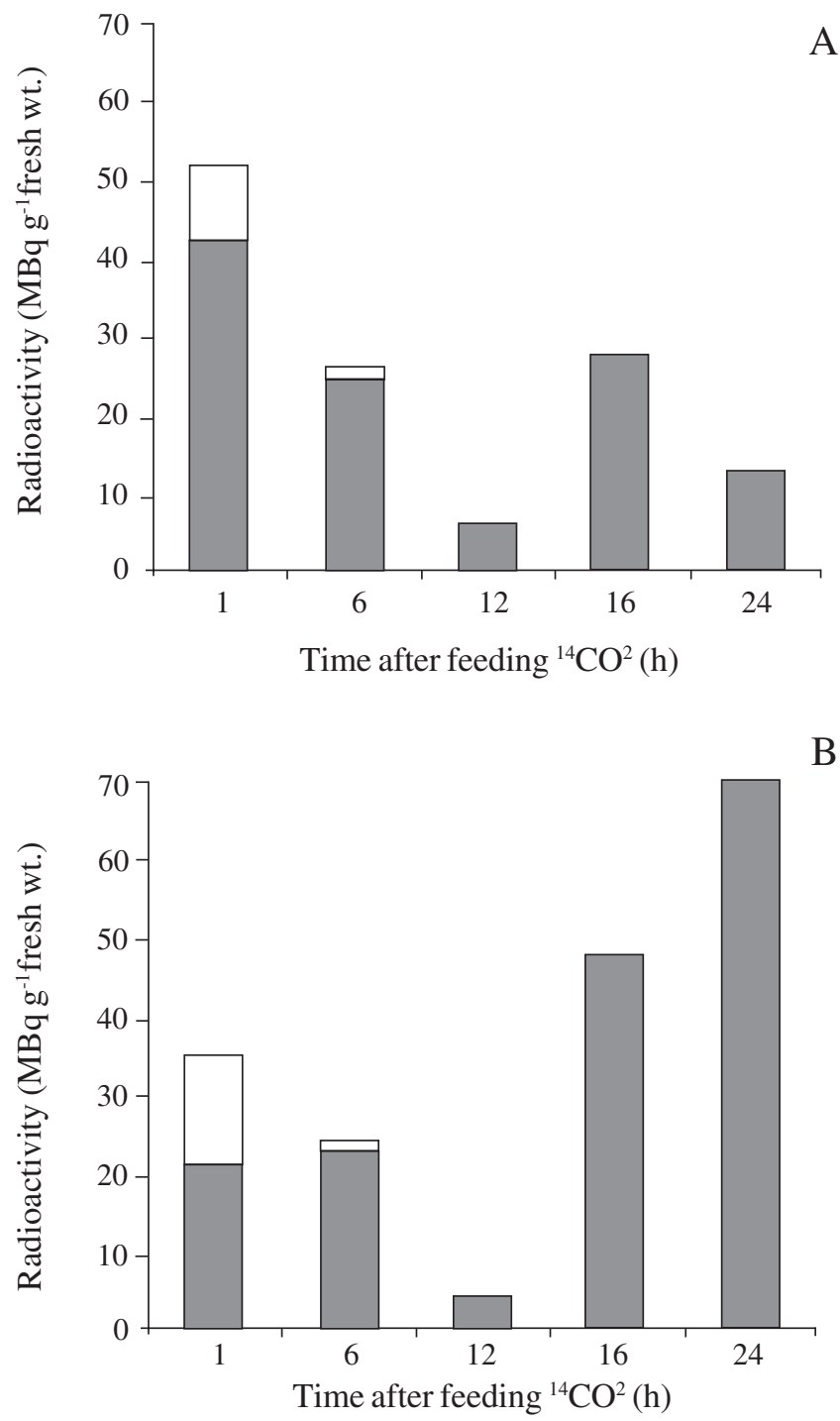

Figure 3. Total radioactivity accumulated in the middle leaves of (A) control and (B) treated plants of L. album at different times after feeding ${ }^{14} \mathrm{CO}_{2}$. $\quad=$ radioactivity in the leaf; $\square=$ radioactivity released as ${ }^{14} \mathrm{CO}_{2}$ by respiration following feeding. Values are means of duplicates. 
A
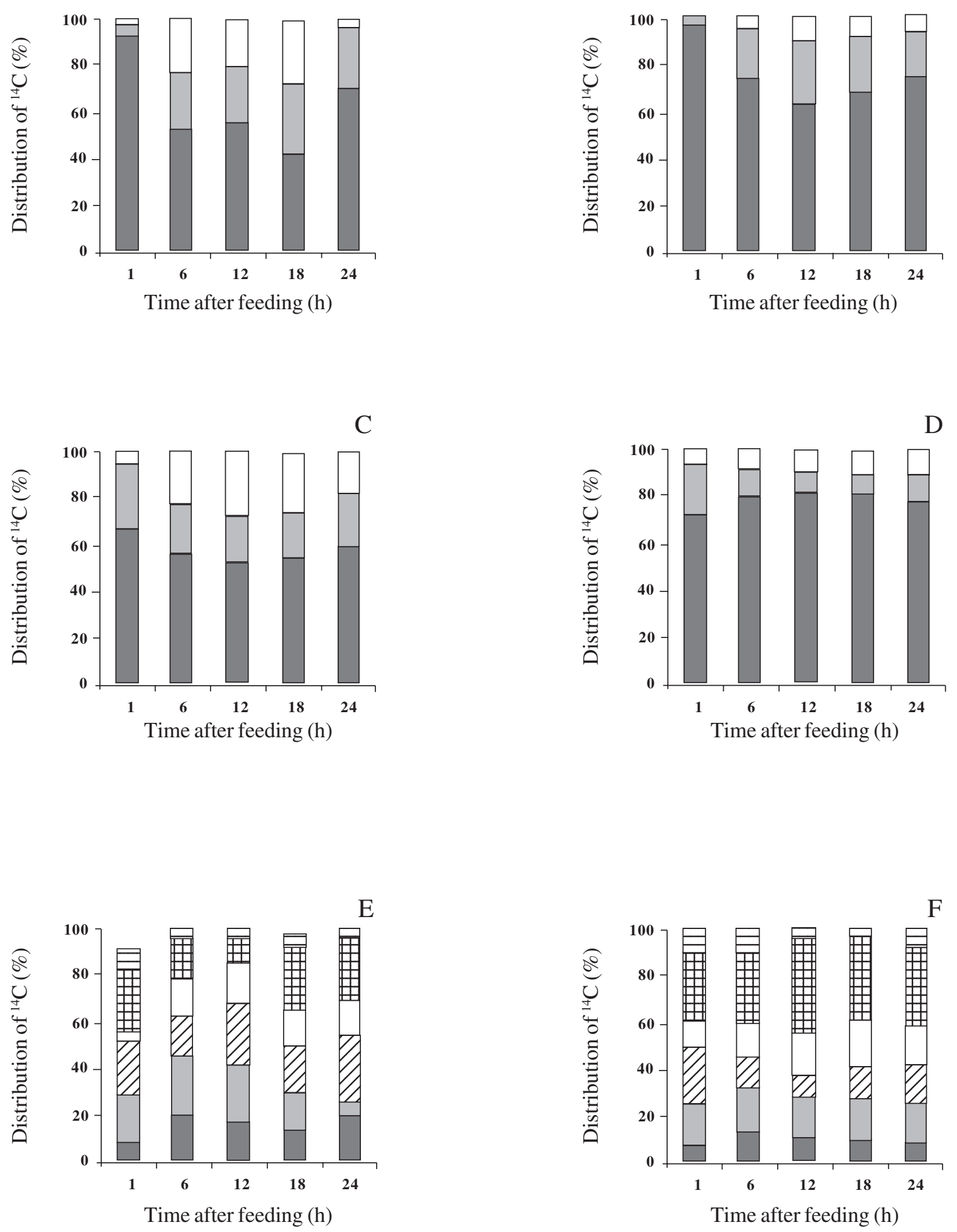

Figure 4. Distribution of radioactivity between various components harvested from control (A, C, E) and treated (B, D, F) leaves of Lamium album at various times after feeding ${ }^{14} \mathrm{CO}_{2} .4 \mathrm{~A}$, B. Distribution between water-solubles $(\square)$, water-insolubles $(\square)$, and starch $(\square)$. 4C, D. Distribution between neutral $(\square)$, basic $(\square)$, and acidic $(\square)$ components of the water-soluble fraction. 4E, F. Distribution between individual sugars within the neutral components. $(\square=$ hexose; $\square=$ sucrose; $\square=$ galactinol; $\square=$ raffinose; 田 = stachyose; $\boxminus=$ verbascose). Values are means of duplicates. 
Enzyme activity - There was a small increase in extractable SPS activity during the day in extracts from leaves of both control and treated plants of $L$. album (figure 5A) despite the increase in sucrose content that accompanies photosynthesis in this species (Kochhar et al. 2002). The increase was greater in extracts from control plants. The apparent sucrose-insensitivity of SPS may be a result of vacuolar sequestration of sucrose. There was a marked decrease in SPS activity in both control and treated plants by $18 \mathrm{~h}(6 \mathrm{~h}$ into the dark period) with a more marked decrease in activity in extracts from treated plants. Activities recovered to control values by $24 \mathrm{~h}$.

A small but statistically significant increase in total soluble acid invertase activity from extracts of both treated and control leaves was observed during illumination (figure 5B). This increase was more marked in extracts from treated leaves, although this difference declined during the subsequent dark period.

\section{Discussion}

Photosynthesis and uptake of ${ }^{14} \mathrm{CO}_{2}$ - Restriction of sink activity was accompanied by a decline in both $\mathrm{CO}_{2}$ uptake and $A_{\max }$ (figures 1,2 ). In cucumber leaves, inhibition of photosynthesis was observed four days after removal of aerial sinks (Mayoral et al. 1985) whereas in temperate gramineae net photosynthesis appears to remain substantially independent of sink activity for some time after experimental manipulation (Natr 1969, Pollock $\&$ Housley 1985). Reductions in net photosynthesis can be caused by stomatal closure (Setter \& Brun 1980, and in this study stomatal conductance and transpirational loss were reduced as a result of sink manipulation. However, intercellular $\mathrm{CO}_{2}$ contents remained similar, suggesting that photosynthetic processes were also inhibited in treated leaves, and this is supported by the decline in $\mathrm{A}_{\max }$ (figure 2). Goldschmidt \& Huber (1992) observed declines in net photosynthesis and $\mathrm{A}_{\max }$ in a range of plants that store both starch and sucrose, suggesting that the ability to accumulate RFOs does not lead to the insensitivity of photosynthesis to assimilate abundance observed during fructan accumulation in temperate gramineae (Pollock \& Housley 1985).

Partitioning of fixed ${ }^{14} \mathrm{CO}_{2}$ between mature leaves and the remainder of the plant was also altered markedly by sink manipulation (figure 3 ). In control leaves, decline in radioactivity following feeding was rapid, although there was some apparent re-allocation of ${ }^{14} \mathrm{C}$ back into the fed leaves during the first part of the dark period. In treated leaves, radioactivity was also lost during the light period but there was extensive re-allocation during the dark period, leading to a considerable excess of radioactivity in treated leaves after $24 \mathrm{~h}$. Autoradiography of the plants (data not shown) confirmed this excess of radioactivity within fed leaves on treated plants. Reduction in sink activity frequently alters carbon partitioning. In sorghum leaves where translocation was blocked completely by steam girdling, an increase in radioactivity in starch was observed (Watson \& Wardlaw 1981). In maize source leaves, increasing sink demand led to an increase in the radioactive sucrose pool (Jeannette et al. 1995). Chilling sinks in vegetative plants of L. temulentum (Simpson et al. 1991) also led to a significant accumulation of soluble material in the source leaves. It appears that the treatments imposed on L. album plants in this study produced changes in photosynthesis and spatial partitioning that are similar to those observed for other species

Metabolic partitioning of ${ }^{14} \mathrm{CO}_{2}$ within mature source leaves - There were significant and progressive differences in the partitioning of ${ }^{14} \mathrm{C}$ within the fed leaves (figure 4). In leaves from treated plants, partitioning of carbon into insoluble material (including starch) was reduced, and there was little evidence of starch mobilisation during the dark period. This contrasted with the greater accumulation of starch in control leaves during the light period and its rapid turnover in darkness (figure 4A, B).

Within the soluble components, partitioning of ${ }^{14} \mathrm{C}$ into acidic and basic compounds was significantly inhibited in leaves from treated plants (figure 4C, D), and this was associated with increased accumulation of ${ }^{14} \mathrm{C}$ in raffinose, stachyose and verbascose. Stachyose was the major soluble sugar in which ${ }^{14} \mathrm{C}$ accumulated in leaves from treated plants, whereas in leaves from control plants, radioactivity was more evenly distributed (figure 4E, F). In leaves from control plants, the accumulation of ${ }^{14} \mathrm{C}$ in sucrose increased during the light period and fell again in darkness. By contrast, the ${ }^{14} \mathrm{C}$ content of sucrose remained similar in leaves from treated plants, with stachyose exhibiting a rise in the light period, followed by a decline in the subsequent dark period. The reduced radioactivity in sucrose and galactinol in leaves from treated plants suggested that there was transfer of radioactivity from these sugars to RFOs. Galactinol is proposed to function as a galactosyl donor in the biosynthesis of raffinose series oligosaccharides (Senser \& Kandler 1967, Kandler 1967). 
These results, taken with the shift away from starch accumulation, indicate that RFO accumulation in L. album is sensitive to the balance between supply of and demand for fixed carbon, and to that extent functions as an analog to fructan accumulation in leaves of temperate gramineae (Pollock et al. 1999). Significant amounts of radioactivity also accumulated in RFOs when L. album plants were exposed to very high irradiance. Under these experimental conditions no radioactivity was present in starch (Kochhar et al. 2003).

Enzymes of sucrose metabolism - Although the changes were not large, mature leaves from treated plants showed significant differences in the extractable activity of both SPS and soluble acid invertase (figure 5). Both of these enzymes are thought to play a key role in regulating sucrose content (Stitt 1996). SPS activity showed a decline in the early part of the dark period,
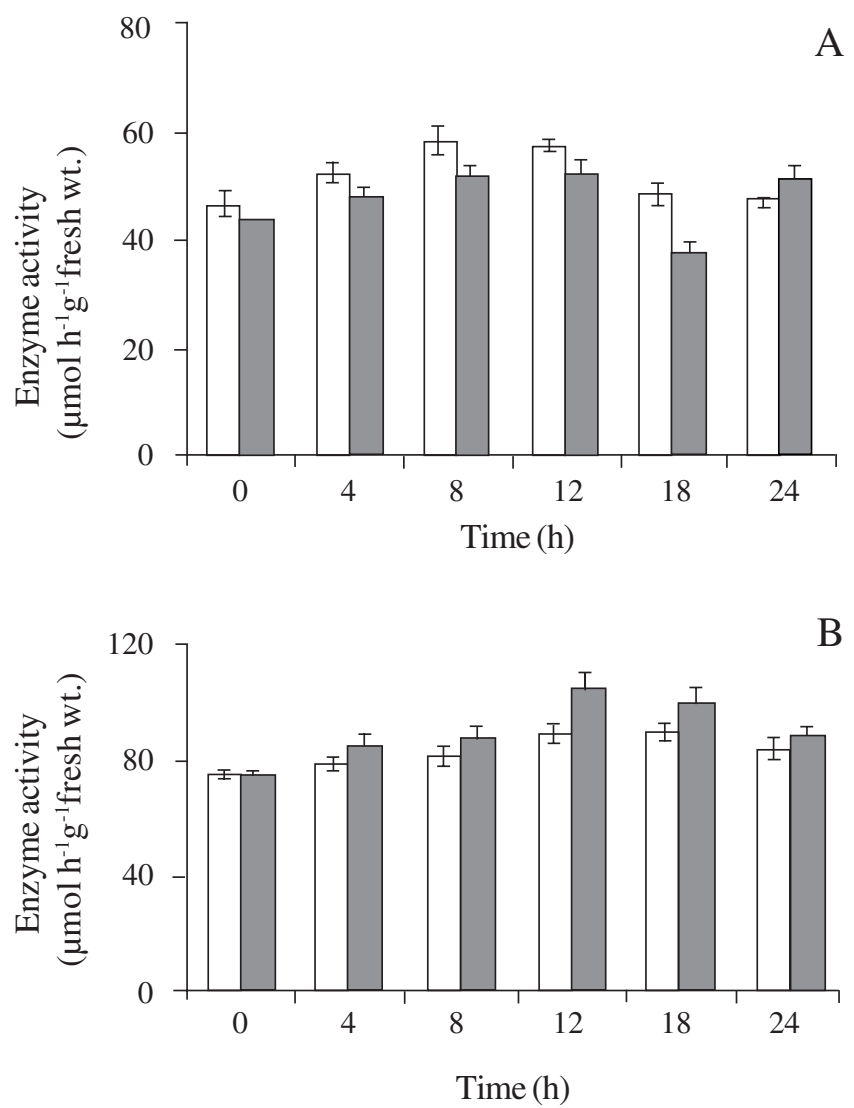

Figure 5. Sucrose phosphate synthase (A) and invertase (B) activities measured in extracts from mature leaves of control (\%) and treated (\%) plants of L. album over a $24 \mathrm{~h}$ period. The thick line on the horizontal axis represents the duration of the dark period. Values are mean \pm sem of five individual samples. Between-treatement differences were significant at the 5\% level (Student's t test) for sucrose phosphate synthase at the $18 \mathrm{~h}$ harvest and for invertase at the $12 \mathrm{~h}$ harvest. which was more marked in leaf extracts from treated plants. This decline has also been observed in other species (Pollock \& Housley 1985). In this study, it is not possible to ascribe regulatory significance to these differences, which may merely reflect differences in substrate or product abundance. We also did not measure the distribution of invertase between vacuole and apoplast or between photosynthetic and heterotrophic tissues. However, Suwignyo et al. (1995) observed a direct correlation between the activity of SPS, sucrose content and carbon dioxide exchange rate in soybean leaves. In turn, vacuolar invertase activity has been proposed to be involved in the regulation of the amount of sucrose in leaves (Huber 1989). A similar decrease in SPS activity and an increase in invertase activity were observed in water-stressed mature maize leaves (Pelleschi et al. 1997). These workers suggested that this was due to a combination of low rate of photosynthesis, lower stomatal conductance and accumulation of sugars.

In L. album, carbon partitioning during sink limitation was shifted away from starch and sucrose towards the synthesis of RFOs. We suggest that this may be linked to a reduction in photosynthetic capacity. This was associated with a reduction in the capacity to synthesise sucrose and an increase in saccharolytic activity.

Acknowledgements - We are grateful to Professor John Farrar (University of Wales, Bangor) for his technical advice. AK acknowledges the Cambridge Commonwealth Hinduja Trust, Downing College Cambridge and The Council of ViceChancellors and Principals for financial support.

\section{References}

FARRAR, J., POLLOCK, C.J. \& GALLAGHER, J. 2000. Sucrose and the integration of metabolism in vascular plants. Plant Science 54:1-11.

GERHARDT, R., STITT, M. \& HELDT, H.W. 1987. Subcellular metabolite levels in spinach leaves. Regulation of sucrose synthesis during diurnal alterations in photosynthetic partitioning. Plant Physiology 83:399-407.

GOLDSCHMIDT, E.E. \& HUBER, S.C. 1992. Regulation of photosynthesis by end-product accumulation in leaves of plants storing starch, sucrose and hexose sugars. Plant Physiology 99:1443-1448.

HOUSLEY, T.L. \& POLLOCK, C.J. 1985. Photosynthesis and carbohydrate metabolism in detached leaves of Lolium temulentum L. New Phytologist 99:499-507.

HUBER, S.C. 1989. Biochemical mechanism for regulation of sucrose accumulation in leaves during photosynthesis. Plant Physiology 91:656-662. 
HUBER, S.C., NIELSEN, T.H., HUBER, J.L.A. \& PHARR, D.M. 1989. Variation among species in light activation of sucrose phosphate synthase. Plant Cell Physiology 30:277-285.

JEANNETTE, E., ROCHER, J.P. \& PRIOUL, J.L. 1995. Effect of an increased sink demand on the carbon metabolism and export of a maize source leaf. Physiologia Plantarum 94:319-327.

KANDLER, O. 1967. Biosynthesis of poly- and oligosaccharides during photosynthesis in green plants. In Harvesting the sun (A. San Pietro, F.A. Grear \& T.J. Army, eds.). Academic Press, New York, p.131-152.

KERR, P.S. \& HUBER, S.C. 1987. Coordinate control of sucrose formation in soybean leaves by sucrose phosphate synthase and fructose 2,6-bisphosphate. Planta 170:197-204.

KINGSTON-SMITH, A.H., GALTIER, N., POLLOCK, C.J. \& FOYER, C.H. 1998. Soluble acid invertase activity in leaves is independent of species difference in leaf carbohydrates, diurnal sugar profile and paths of phloem loading. New Phytologist 139:283-292.

KOCHHAR, A., AP REES, T. \& POLLOCK, C.J. 2003. Carbohydrate metabolism in leaves of Lamium album L.: photosynthesis and carbon partitioning throughout the photoperiod. Revista Brasileira de Botânica 26:525-531.

LEWIS, C.E., PERATONER, G., CAIRNS, A.J., CAUSTON, D.R. \& FOYER, C.H. 1999. Acclimation of the summer annual species Lolium temulentum to $\mathrm{CO}_{2}$ enrichment. Planta 210:104-114.

LYNE, R.L. \& AP REES, T. 1971. Invertase and sugar content during differentiation of roots of Pisum sativum. Phytochemistry 10:2593-2599.

MAYORAL, M.L., PLAUT, Z. \& REINHOLD, L. 1985. Effect of translocation-hindering processes on source leaf photosynthesis in cucumber. Plant Physiology 77:712-717.

NATR, L. 1969. Influence of assimilate accumulation on rate of photosynthesis in barley leaf segments. Photosynthetica 3:120-126.
PELLESCHI, S., ROCHER, J.P. \& PRIOUL, J.L. 1997. Effects of water restriction on carbohydrate metabolism and photosynthesis in mature maize leaves. Plant, Cell and Environment 20:493-503.

POLLOCK, C.J. \& HOUSLEY, T.L. 1985. Light-induced increase in sucrose phosphate synthetase activity in leaves of Lolium temulentum. Annals of Botany 55:593-596.

POLLOCK, C.J., CAIRNS, A.J., GALlAGHER, J., MACHADO-DE-CARVALHO, M.A. \& KOCHHAR, A. 1999. The metabolism of sugars based upon sucrose. In Plant carbohydrate biochemistry (J.A. Bryant, M.M. Burrell \& N.J. Kruger, eds.). Bios Scientific Publishers, Oxford, p.47-60.

SENSER, M. \& KANDLER, O. 1967. Vorkommen and verbreitung von Galactinol in Blättern höherer Pflanzen. Phytochemistry 6:1533-1540.

SETTER, T.L. \& BRUN, W.A. 1980. Stomatal closure and photosynthetic inhibition in soybean induced by petiole girdling and pod removal. Plant Physiology 65:884-887.

SIMPSON, R.J., WALKER, R.P. \& POLLOCK, C.J. 1991. Fructan exohydrolase activity in leaves of Lolium temulentum L. New Phytologist 119:499-507.

STITT, M. 1996. Metabolic regulation of photosynthesis. In Photosynthesis and the environment (N.R. Baker, ed.). Kluwer Academic Publishers, Dordrecht, p.151-190.

SUWIGNYO, R.A., NOSE, A., KAWAMITSU, Y., TSUCHIYA, M. \& WASANO, K. 1995. Effect of manipulation of source and sink on the carbon exchange rate and some enzymes of sucrose metabolism in leaves of Soybean (Glycine max (L.) Merr.). Plant Cell Physiology 36:1439-1446.

WALKER, R.P., WINTERS, A.L. \& POLLOCK, C.J. 1997. Purification and characterisation of invertases from the leaves of Lolium temulentum. New Phytologist 135:259-266.

WATSON, B.T. \& WARDLAW, I.F. 1981. Metabolism and export of ${ }^{14} \mathrm{C}$-labelled photosynthate from water stressed leaves. Australian Journal of Plant Physiology. 8:143-153. 